\title{
A Study on Noun Suffixes: Accounting for the Vernacularisation of English in Late Medieval Medical Texts
}

\author{
Begoña Crespo (Coruña, Spain)
}

\begin{abstract}
This paper seeks to contribute to the study of the vernacularisation process in late Middle English by measuring up to what an extent concrete and abstract noun suffixes (in line with Dalton-Puffer 1996) attach to either Germanic or Romance bases in the medical texts extracted from the MEMT (Middle English Medical Texts) corpus. The findings obtained have been further described according to text type or genre and to target audience/readership. The description of these suffixes in relation to all the parameters already mentioned has confirmed the predominance of abstract suffixes of Romance origin although Germanic abstract suffixes are also abundant. More hybrid formations have been found with Germanic noun suffixes than with Romance ones which might be indicative of their versatility towards vernacularisation.
\end{abstract}

\section{Introduction}

The aim of this paper is to explore the occurrence and productivity of noun ${ }^{1}$ suffixes in medieval medical texts, as a means of verifying the level of vernacularisation of "science" 2 at the time of the birth of English for Specific Purposes (ESP). As Voigts (1989) and Taavitsainen and Pahta (1997) have noted, the vernacularisation process in English dates back to the last quarter of the 14th century. The influence of Latin on writing was strong at this time, but the vernacular and its idiosyncrasies were gradually gaining ground in protoscientific discourse. The role played by foreign word formation cannot be left aside. Loanwords are to some extent an obstacle to productivity in a language; however, broadly speaking borrowings also have a specific referential value in terms of social prestige as compared to vernacular terminology. In the case of Late Medieval English, Latinate words added learnedness to texts aimed at whatever level of readership, and were useful for pragmatic purposes, not merely for filling lexical lacunae. The creation and use of disciplinespecific language, though, also calls for the knowledge of discipline-specific vocabulary on which it depends (cf. Dahl 1989).

Science writing in the vernacular brought about the birth of new epistemic communities whose social role was more a matter of the practical application of knowledge to everyday situations than theoretical debate. Moreover, we should bear in mind that, as Kaplan (2001: 14) has stated, "science is an important candidate for promoting the growth of a standard language because it uses a common set of methods and measurement-standards". Taavitsainen (2001: 188) echoes Kaplan's position, arguing that the rise of scientific writing in English can

\footnotetext{
${ }^{1}$ Dalton-Puffer (1996) observes that nouns have been investigated in much more detail than any other lexical category and calls for the study of word-formation processes in adjectives, verbs and adverbs. Still, I have decided to analyse nouns because this is a well-known representative category in scientific writing (Sager et al. 1980; Nevalainen 1999) and allows for comparison with Dalton-Puffer's and other authors' results.

2 What was understood by science in the Middle Ages remains distant from our $21^{\text {st }}$ century view moulded on the new-born model after Empiricism.
} 
be associated particularly with the Central Midland standard. The process of vernacularisation is a necessary step prior to standardization. English, although still under Latin dominance, begins to operate as a language for the transmission of specific content. In this way, it will come to be coloured by new coinages, specialisation of meaning (cf. Gotti 2011; Crespo 2011), metonymy, changes of material culture (cf. Görlach 2003) and word formation processes.

My point of departure is the presence of certain vernacular pieces in the morphological jigsaw of scientific English, looking at the nature of derivation, suffixation in particular. The influence of the classical languages can be seen here at a higher level than in compounding at this moment in history. As Matthews (1974: 124f.) has observed: "The English language tendency to suffixation continues a characteristic of Indo-European which has substantially resisted change through the millennia". Evidence for this can be found in Norri's 1998 work where, in an analysis of medical vocabulary, he observes the preference for suffixation over prefixation in terminology for body parts.

It is also my intention to ascertain whether the genre of the text and, consequently, the type of addressee, leads the author to modify his morphological strategies (native/foreign bases combined with native/foreign suffixes) in the use of derivation.

To this end, the paper will be divided into four different sections. Section 1 will offer a short revision of some aspects of derivation in late Middle English. In the second section the selection of the corpus material and the methodology used will be explained. Section 3 will analyse all the data gathered according to two variables: etymology and text type. Finally, section 4 will present the conclusions reached in the light of previous results.

\section{Some aspects of derivation in late Middle English}

Bauer (1983: 225) notes that derivative forms can be considered from two different points of view: on the one hand, there are some derivatives in the source language that have been adopted as such by the recipient language, whereas other derivative forms develop from within the language. Most of the cases I have found in the samples of Middle English Medical Texts (MEMT) corpus appear to belong to the first group. This mirrors Lenski (2000: 1), who argues that the classical influence on English morphology has been "strong and lasting (...) in scientific and abstract vocabulary". In my material, most of the loanwords adopted were morphologically complex in the source language. In my opinion, it is probable that late Middle English derivative formations are rare because many vocabulary items continued to be introduced into the language at this time, and users of this register would have taken time to assimilate foreign words and use them in native-like processes of coining new terms. It would be even longer before language users combined native and borrowed units into hybrid formations. Nevertheless, some instances can be attested in Middle English texts.

As Halliday (1978) has claimed, in the field of scientific terminology three strategies were commonly used in late Middle English: the reinterpretation of existing words to endow them with a specialised meaning, native word formation, and borrowing, mainly from classical languages. For the present analysis I will focus on derivative loans and the creation of new words, particularly hybrid formations (Germanic and Romance suffixes combining with Germanic/Romance bases).

Foreign words were adopted as building blocks, bringing with them their own structure, including affixes and meanings. Initially, these terms were considered foreign by speakers, but as they spread among the discourse community they gradually became familiar, as did their affixes (cf. Burnley 1992: 445f.; Runblad 1998; Castairs-Mccarthy 2002: 103), leading to the combination of foreign affixes with native roots and vice versa (unknowable, 
colourless). In the scientific register of the late Middle Ages loanwords were frequently taken from other languages, but they were regarded as particularly foreign, not least because this was a new register, transmitted through the written medium. This was, obviously, an added difficulty to have access to the scientific register. In addition, most of these texts were addressed not to the general public but to scholarly elites. However, when the topic of a text concerned non-academic people more directly, the degree of vernacularisation of the text tended to be higher (cf. Taavitsainen 2004). In her study of derivational morphology, looking principally at suffixation in Middle English texts (1150-1420) taken from the Helsinki Corpus of English Texts (HC, henceforth), Dalton-Puffer (1996) concluded that French derivational patterns did not play a dominant role in the evolution of English word based morphology. Her analysis assesses the frequency and type of hybrid formations found in those texts, as a possible way of measuring the productivity of suffixes, and points to the predominance of the combination Romance base + Germanic suffix and not vice versa. This interpretation might indicate that native suffixes tend to be more versatile and productive than French ones, hence the low level of influence of French on Middle English derivational patterns. In the same vein, Jakubowsky (2006) described the characteristics of suffixation in three Middle English romances, concluding that native suffixes are more productive than foreign ones, which underlines, once more, the lack of significance of the French patterns when applied to derivation. The tendency for native suffixes to be highly productive, seen in the work of both Dalton-Puffer and Jakubowsky in different text types (sermons, travelogue, history, handbooks, poetry ...), will be tested in my current analysis of Medieval medical texts; these will be further subdivided into three layers according to addressee.

The analysis of noun suffixes presented by Dalton-Puffer in her 1996 book The French influence on ME Morphology. A Corpus-based study of derivation, provides the basis for this discussion. She establishes a distinction between abstract and concrete noun suffixes. Both groups include types from two main etymological sources: Germanic and Romance languages. Tables 1 and 2 below contain the most common abstract and concrete noun suffixes which have been extracted from the $H C$ and examined in detail by Dalton-Puffer (1996) and which will be considered in the present paper:

\begin{tabular}{|ll|}
\hline Germanic & \\
\hline -DOM & $<$ dom(e), dam $>$ \\
\hline $\begin{array}{l}\text {-HEDE } \\
\text { hiede }>\end{array}$ & $<$ had(e), hat, head, hede, heed, ho(o)d, \\
\hline -LAC & $<$ lac, lec, leac, lacke, le33æe $>$ \\
\hline -NESS & $<$ nesse, nes, nisse, nysse $>$ \\
\hline -REDEN & $<$ redden, ræden $>$ \\
\hline -SHIP & $<$ schipe, chipe, scipe, schepe, shippe, sipe $>$ \\
\hline -TH & $<$ Te, th(e), de $>$ \\
\hline -UNG & $<$ ung, ing, yng(e) $>$ \\
\hline Romance & \\
\hline -ACY & $<$ acy, acie $>$ \\
\hline -AGE & $<$ age $>$ \\
\hline -AL & $<$ al $>$ \\
\hline -AUNCE & $<$ ance, ence, aunce, aunse $>$ \\
\hline
\end{tabular}




\begin{tabular}{|ll|}
\hline -ACIOUN & $<$ (a)cion, (a)cioun, ation $>$ \\
\hline -ERIE & $<$ rie, ry(e), ie $>$ \\
\hline -ITE & $<$ ite, itee, ete, te $>$ \\
\hline -MENT & $<$ ment $>$ \\
\hline
\end{tabular}

Table 1: Abstract nouns suffixes

\begin{tabular}{|l|l|}
\hline Germanic & Romance \\
\hline -ERE & -ANT \\
\hline -END & -ARD \\
\hline -ILD & -ARY \\
\hline -ESTRE & -EREL \\
\hline -LING & -ESSE \\
\hline -EL & -IST \\
\hline & -ISTRE \\
\hline & -OUR \\
\hline
\end{tabular}

Table 2: Concrete noun suffixes ${ }^{3}$

In the following sections I will address the analysis of these suffixes in data extracted from a specific corpus of medieval medical texts.

\section{Corpus selection and methodology}

I have used the MEMT corpus, compiled in Helsinki by Taavitsainen, Pahta and Mäkinen (2005) to analyse the degree of vernacularisation present in medieval "technical" texts, by testing the productivity of Romance and Germanic derivative patterns. The part of MEMT used contains samples of texts written between 1375 and 1500 and an Appendix of texts written ca. 1330. As already mentioned, these texts are subdivided into 3 different writing traditions or text types: 'specialized treatises', 'surgical treatises' and 'remedybooks and materia medica'. There is a fourth group of texts written in verse which has not been taken into consideration in the present study. As a result, 73 texts totaling 444,829 words will be used, as shown in Table 3.

\begin{tabular}{|l|l|l|l|}
\hline Surgical & Specialised texts & $\begin{array}{l}\text { Remedies and } \\
\text { Materia medica }\end{array}$ & Total \\
\hline 137,498 & 88,414 & 218,917 & 444,829 \\
\hline
\end{tabular}

Table 3: Number of words

All suffixes proposed by Dalton-Puffer (1996) have been searched for in these texts, including spelling variants. Identifying suffixes from either Germanic or Romance languages allows us to consider etymological origin as a significant variable. Given the important role of the intended audience in vernacularisation (cf. Taavitsainen 2004: 38), a further variable will be that of the text type to which a sample belongs, as this implies a corresponding type of

\footnotetext{
${ }^{3}$ Spelling variants are not included in this case. I have adhered to the searches done by Dalton-Puffer (1996).
} 
audience/readership. Both variables will be investigated in the two types of suffixes: abstract and concrete noun suffixes. As for this latter variable, Pahta and Taavitsainen (2004: 14f.) explicitly mention the threefold classification of medical material written during the Middle English period, noting that several studies have provided empirical evidence for the existence of these text categories. From the most specialised to the least learned texts they are classified as 'specialized', 'surgical' and 'remedybooks', as noted above.

Getz (1998: 36) observed that "there are two trends in medical writing: one derived from the Greco-Arabic tradition translated into Latin and a more familiar or empirical one derived from the writings of those classical authors who relied on traditional wisdom". These trends are indeed represented in the samples under study here. Specialised texts testify to the scholarly interest of the learned elite, and conform to the patterns of classical scholarship; such texts were written in Latin. Surgical treatises had a more practical aim, comprising surgical and anatomical description, yet were also written in Latin more often than not. Finally, remedybooks were of a more popular nature, and included recipes, herbals and the like, and were mainly written in the vernacular due to their instructional function. The intended audience of the second and third of these text types would have been heterogeneous, including both lay readers and medical professionals of different levels (cf. Getz 1998: 17). The relationship between the recipient of these text types ${ }^{4}$ and the morphological strategies employed will be examined below.

\section{$4 \quad$ Analysis of Data}

Two classes of noun suffixes will be considered in the analysis of data: abstract noun suffixes and concrete noun suffixes. Only tokens will form part of the analysis, and nothing will be said about types. The reason for this is that I am interested in measuring the productivity of a particular word formation process, suffixation, by retrieving the frequency of use of these two classes of suffixes. Therefore, type frequency in itself does not add any valuable information to the present study.

Beginning with a general analysis, we have found a total of 9,715 tokens of noun suffixes that can be distributed according to semantic class (abstract/concrete), origin (Romance/Germanic) and text type (Specialised/Surgical/Remedies).

\begin{tabular}{|l|l|l|l|}
\hline & Abstract & Concrete & Total \\
\hline Romance & 5,258 & 306 & 5564 \\
\hline Germanic & 3,988 & 163 & 4151 \\
\hline TOTAL & $\mathbf{9 , 2 4 6}$ & $\mathbf{4 6 9}$ & $\mathbf{9 7 1 5}$ \\
\hline
\end{tabular}

Table 4: Noun suffixes. Semantic class and etymology

Abstract noun suffixes $(9,246)$ overwhelmingly exceed those of the concrete class (469). The prevailing scholastic patterns of argumentation, elaboration and explanation are still present in these Late Medieval texts selected by the MEMT compilers. Although two different epistemological levels can be found in the field of medicine in general (science and craft), the most abstract and explanatory level, in which medicine is referred to as a science or university discipline, seems to predominate, as the frequency of the corresponding suffixes indicate. It is curious to note, however, that surgical treatises $(5,086.90$, normalised frequency) contain more abstract forms than specialised texts $(4,880.27)$ as will be seen in table 7 below.

\footnotetext{
${ }^{4}$ The use of the terms text type/genre is a highly controversial issue and its discussion falls outside the scope of this paper.
} 
Quantitatively speaking, Romance noun suffixes outnumber Germanic ones, yet the difference is not overwhelming. In principle, this could be seen as evidence of a gradual tendency towards vernacularisation in medical writing, but more information is required before a stable and firm tendency can be shown conclusively. Dalton-Puffer found more examples of a Germanic origin in a different corpus, the $H C$, which included samples from different text types with different content, encompassing homilies, history, law, fiction, private letters, official letters, drama, etc.

Remedybooks is the text type with the highest number of tokens. The highest frequency of occurrence of Romance suffixes here once again testifies to the vernacularisation process, since the use of these Romance suffixes in texts mainly addressed to laymen implies that the suffixes used here (used by the speaker or writer and understood by the hearer) were accepted and internalised by the whole speech community. In fact, texts in both the surgical and remedybooks categories share a very similar proportion of Germanic nouns suffixes $(5.16 \%$, $5.41 \%$, respectively) whereas specialised texts contain a lower percentage (3.8\%).

A description of the different classes of noun suffixes found in the research material will now be presented.

\subsection{Abstract noun suffixes}

From all the noun suffixes (9,715 tokens) found in this corpus, 9,246 (95.17\%) are abstract. The predominance of abstract elements might be explained in terms of the inheritance of medieval scholastic patterns of writing science, which were regarded as more speculative in nature and, consequently, resorted more readily to abstractions than to practical, concrete forms of explanation. Both groups of suffixes will now be examined, taking into account two variables: etymological origin and text type. The addressee plays an essential role in the latter variable.

\subsubsection{Etymological origin}

Findings ${ }^{5}$ from the analysis of the corpus for etymological origin are set out in tables 5 and 6 below:

\begin{tabular}{|l|l|l|l|l|l|l|}
\hline & Surgical & nf & Specialised texts & $\mathbf{n f}$ & $\begin{array}{l}\text { Remedies and } \\
\text { materia medica }\end{array}$ & TOTAL \\
\hline -DOM & 3 & 4.77 & 6 & 14.85 & 12 & 21 \\
\hline -HEDE & 1 & 1.59 & 2 & 4.95 & 11 & 14 \\
\hline -LAC & 5 & 7.96 & 5 & 12.38 & 6 & 16 \\
\hline -NESS & 155 & 246.78 & 369 & 913.66 & 783 & 1307 \\
\hline -REDEN & 0 & 0 & 0 & 0 & 0 & 0 \\
\hline -SHIP & 22 & 35.02 & 1 & 2.47 & 17 & 40 \\
\hline -TH & 13 & 20.69 & 2 & 4.95 & 128 & 143 \\
\hline -UNG & 1096 & $1,744.99$ & 430 & $1,064.69$ & 921 & 2447 \\
\hline TOTAL & 1295 & $\mathbf{2 , 0 6 1 . 8 0}$ & 815 & $\mathbf{2 , 0 1 7 . 9 5}$ & $\mathbf{1 8 7 8}$ & 3988 \\
\hline
\end{tabular}

Table 5: Abstract noun suffixes of Germanic origin

\footnotetext{
5 Since the number of words from the samples of each writing tradition is different, I have decided to normalise figures ( $\mathrm{nf}$ henceforth) to the number of words of the biggest set $(218,919$ in this particular case; see table 3 above) (Lareo 2009: 275).
} 


\begin{tabular}{|l|l|l|l|l|l|l|}
\hline & $\begin{array}{l}\text { Surgic } \\
\text { al }\end{array}$ & $\mathbf{n f}^{6}$ & $\begin{array}{l}\text { Specialise } \\
\text { d texts }\end{array}$ & nf & $\begin{array}{l}\text { Remedies } \\
\text { and materia } \\
\text { medica }\end{array}$ & $\begin{array}{l}\text { TOTA } \\
\text { L }\end{array}$ \\
\hline -ACY & 10 & 15.92 & 1 & 2.47 & 11 & 22 \\
\hline -AGE & 23 & 36.61 & 40 & 99.04 & 63 & 126 \\
\hline -AL & 32 & 50.94 & 13 & 32.18 & 12 & 57 \\
\hline -AUNCE & 318 & 506.30 & 280 & 693.29 & 740 & 1338 \\
\hline - & 834 & 1327.85 & 422 & 1044.89 & 589 & 1845 \\
\hline ACIOUN & & & & & & \\
\hline -ERIE & 131 & 208.57 & 116 & 287.22 & 218 & 465 \\
\hline -ITE & 451 & 718.05 & 187 & 463.02 & 401 & 1039 \\
\hline -MENT & 101 & 160.80 & 97 & 240.17 & 168 & 366 \\
\hline TOTAL & 1900 & $\mathbf{3 , 0 2 5 . 0 4}$ & 1156 & $\mathbf{2 , 8 6 2 . 2 8}$ & $\mathbf{2 2 0 2}$ & $\mathbf{5 2 5 8}$ \\
\hline
\end{tabular}

Table 6: Abstract noun suffixes of Romance origin

A total of 9,246 tokens of abstract noun suffixes has been found. Of these, 5,258 (57\%) are of Romance provenance and 3,988 (43\%) are Germanic in origin, and although Romance predominate, the distance between the two is relatively modest. One might argue that the presence of vernacular elements in the formation of abstract nouns proves that these words, and the texts containing them, were accessible to the non-learned. Moreover, orientating written "technical" language to the intended audience/readership is, of course, a way of disseminating knowledge more effectively.

The relatively balanced presence of suffixes from Romance and Germanic origins might be interpreted as a consequence of the efforts of authors who, whilst engaging in the vernacularisation of the language, cannot leave Latin wholly aside because it forms part of their education and cultural background. Latin exerts a heavy influence on English but it is also a necessary source to cover the lexical lacunae that opened up as a result of social development (cf. Moessner 2003; Kastovsky 2006; McIntyre 2008; Gotti 2011). The figures here reflect the degree of exploitation of vernacular resources in a specific domain, and the percentages are quite close. Such a finding might also be interpreted as especially valuable in that we are looking at a particular register; not common, everyday English but a diatopic variety which illustrates the fight for English to be present in all spheres of life. The native tongue is being widely used by speakers ascending the social ladder, to the point at which it can be regarded as a prestigious vehicle of communication. Contrary to Taavitsainen's postulate (2001: 188) that "prestige is not a function of socio-economic power but education" I believe that prestige and power run in parallel, and in the power structure of the late Middle Ages, education and the social elite served as a single, irrepressible force. It could be said that this was a change from above (cf. Labov 1972) in the sense that those occupying the upper parts of the social pyramid, both in terms of knowledge and power, paved the way for future generations of English users (cf. Crespo/Moskowich 2009). Thus, I concur with Taavitsainen (2001: 188) that "scientific writing is a spearhead of culture in indicating future directions; vernacularisation of texts in this register is important for any nation".

\footnotetext{
${ }^{6}$ Figures have been normalised according to the text type with the largest number of words. In this case it is Remedies and materia medica.
} 
If we analyse separately each origin we can observe that in the case of Romance suffixes the distribution is as shown in Graph 1 below:

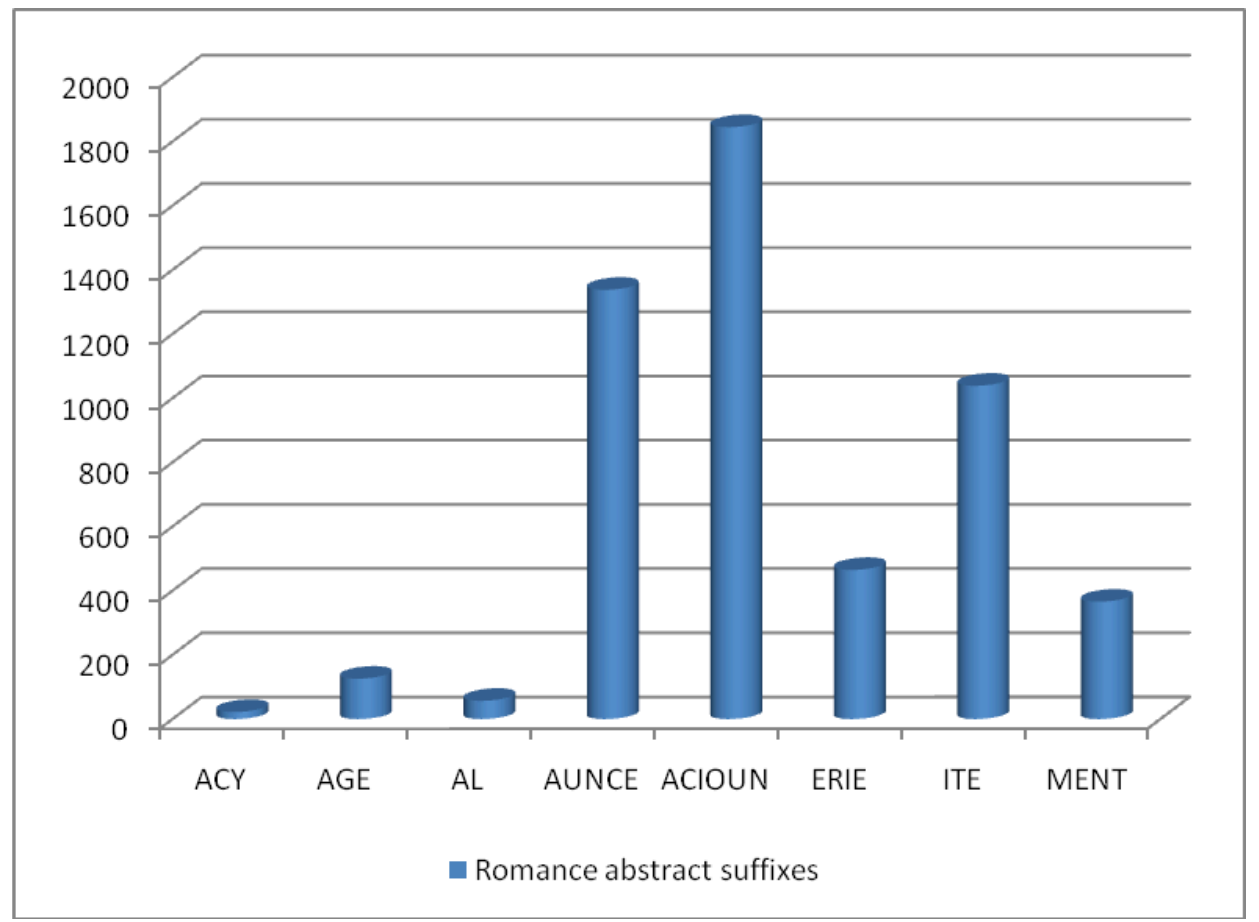

Graph 1: Romance suffixes

The greatest number of occurrences corresponds to -aunce, -acioun, -ite. The deverbal suffix acioun (act of V-ing; state of being Pp-ed) is also very frequent in the Middle English texts of different types in the Helsinki Corpus (cf Dalton-Puffer 1996: 94). Similar behaviour can be observed in another de-verbal suffix, -aunce (action of V), though it may also be de-adjectival with the subsequent variation of meaning (state of being A) (Plag 2003). The result is the coexistence and functional distribution of both suffixes ${ }^{7}$. However, the frequency of occurrence of -acioun (1845 instances) is higher than that of -aunce (1338 instances), although -acioun is mainly recorded in surgical and specialised texts.

The different types of Germanic suffixes under survey are distributed as follows:

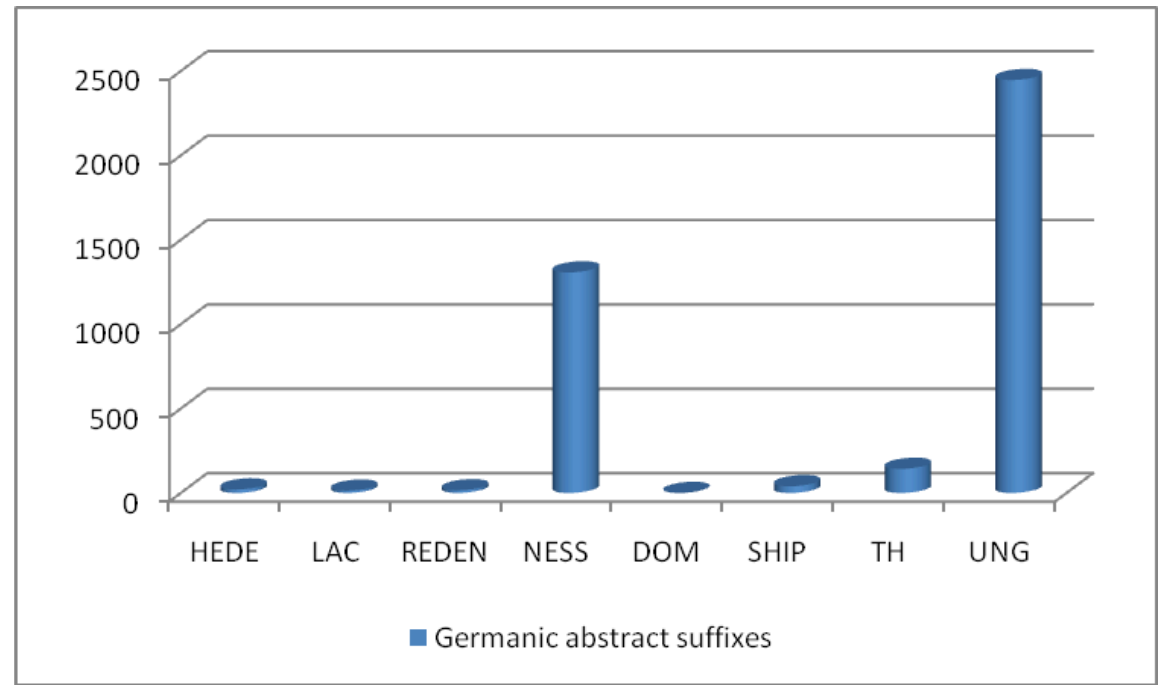

Graph 2: Germanic suffixes

\footnotetext{
${ }^{7}$ See Ciszek (2006) for more information on other examples of Romance suffixes.
} 
-ung and -ness are the most frequent (2,447 and 1,307 tokens, respectively). Third is -th (143 tokens), but at a significantly lower frequency than the first two. -Ness is a versatile suffix, and its high productivity can be explained in that it allows formations on a great number of bases, adjectives, verbs, pronouns, numerals and nouns (cf. Dalton-Puffer 1996), even hybrid formations with Romance bases, such as those attested in our data: costifnise, contrarieusness, egalnesse, faireness, febylnesse, schamefastnes, inprofitable, secretenesse and in doublets with a clarifying function where there is a base from each provenances: the durenesse or hardnesse.

The OE suffix -ung is the most frequently occurring, representing $61.35 \%$ of all Germanic suffixes. As Marchand (1969: 302) has noted, "in ME -ing developed the new function of forming verbal substantives" and this can be clearly contrasted in these data. Of course, I am here dealing with its derivational role, especially that of forming nouns, since verbal and adjectival forms have been omitted from the analysis. To establish the distinction between nominal and other forms, I have been guided by the syntactic context as well as the existence of certain syntagmatic elements accompanying the -ing forms which help it take on a nominal character. They can be listed as follows:

- The presence of articles, both definite and indefinite

- Possessive determiners

- Premodification by an adjective or noun

- Occurrence in plural number

- Post-modification by an of-phrase

- Subject, object position

Examples (1) to (11) may serve to illustrate -ing forms which have been included in this study:

(1) His fillinge of

(2) Of the lyuere norischinge

(3) A demonstracioun, a shewyng

(4) The couerynge of the body

(5) The makynge of mannys body

(6) With anoyntyngis of oyle of bawme

(7) Aftir the anoyntynge of the oyle

(8) The comoun helynge of woundis

(9) A good boilynge

(10) The gendrynge is lost

(11) The helynge of apostymes

There are also some examples of combinations of -ing suffixes with Romance bases, such as fleobotomying, cauteri3ing, dieting. Other word formation processes are also seen, like prefixation in vnkonnyng; in this case, hybridisation can be found in the following combination: the base is of Romance origin, to which a Germanic suffix is added. In hybrids vernacularisation can be attested in the use of native suffixes such as -ing which represents one of the vernacular solutions to create abstract terminology. 
-ing verbal and adjectival forms have been discarded from my analysis. This is the case with (12) and (13) below:

(12) a restinge place

(13) fleshes fulfillynge the voyde places

Doublets have also been found with this suffix, as in (14):

(14) Alle the insciciouns or kyttynges of the hede schal be made

It is notable that when doublets are used the two forms with the same referent are coordinated but the provenance of the terms is clearly different, Latin/French vs Old English origin.

\subsubsection{Text type/genre}

The second variable is that of text type, or "writing tradition" as it is often referred to by corpus compilers. Interestingly enough, there is a connection between addressee and the purpose of the text, and this effectively renders the level of specialisation of the text a typological marker. In principle, then, the hypothesis that follows is that the more specialised a text, the higher the level of education of the target readers and, consequently, the higher its social position. Likewise, a high level of abstraction will be associated with a high level of education and to the knowledge of Latin and French.

Table 7 below shows the presence of abstract noun suffixes in each layer:

\begin{tabular}{|l|l|l|l|l|l|}
\hline & Surgical & nf & Specialised texts & nf & $\begin{array}{l}\text { Remedies and } \\
\text { materia medica }\end{array}$ \\
\hline Romance & 1900 & $3,025.07$ & 1156 & $2,862.30$ & 2202 \\
\hline Germanic & 1295 & $2,061.83$ & 815 & $2,017.97$ & 1878 \\
\hline TOTAL & 3195 & $\mathbf{5 , 0 8 6 . 9 0}$ & 1971 & $\mathbf{4 , 8 8 0 . 2 7}$ & $\mathbf{4 0 8 0}$ \\
\hline
\end{tabular}

Table 7: Abstract noun suffixes in different writing traditions

The greatest number of abstract suffixes (5086.90) is found in surgical treatises. This writing tradition is followed by specialised texts (4880.27) and remedybooks (4080). Although Romance origins predominate in all three text types, the gap between Germanic and Romance origin of abstract suffixes in surgical treatises is the largest. It is in remedybooks that we can appreciate closer figures for both Romance and Germanic types (2202 and 1878, respectively). This might be interpreted as the growing presence of vernacular forms that are pushing against the morphological traces of Latin's influence. This is the least technical text type, and we might expect that these texts would have been addressed to a less learned audience. I have already observed that the vernacularisation process can also be verified in the highest number of postponed adjectives of Germanic origin in this, the least technical text type (cf. Moskowich 2009), precisely where I have found a high number of native suffixes.

\subsection{Concrete noun suffixes}

There is only a low number of concrete noun suffixes in the data. Such a dearth of material precludes any definitive remarks, but this very low number (469, see table 4 above) may itself be symptomatic of the sort of vocabulary items which were less frequently used in early scientific discourse. Findings here will be presented according to the variables of etymology and text type, as was the case with abstract noun suffixes. 


\subsubsection{Etymological Origin}

Concrete noun suffixes of Romance origin stand out here, with $65.24 \%$ of all occurrences, as opposed to $34.76 \%$ from Germanic origin, although it is not so striking to observe that most of these (125 cases) were found in surgical texts, which are addressed to an intermediate level readership, both practitioners and laymen. Almost the same number of cases from both origins is found in remedybooks, but this ratio is radically different in the case of specialised texts (72 Romance, 2 Germanic). All the findings are laid out in tables 8 and 9:

\begin{tabular}{|l|l|l|l|l|l|l|}
\hline & Surgical & $\mathbf{n f}$ & $\begin{array}{l}\text { Specialised } \\
\text { texts }\end{array}$ & $\mathbf{n f}$ & $\begin{array}{l}\text { Remedies and } \\
\text { materia medica }\end{array}$ & TOTAL \\
\hline -ERE & 0 & 0 & 1 & 2.47 & 69 & 70 \\
\hline -END & 0 & 0 & 0 & 0 & 0 & 0 \\
\hline -ILD & 0 & 0 & 0 & 0 & 0 & 0 \\
\hline -ESTRE & 0 & 0 & 0 & 0 & 0 & 0 \\
\hline -LING & 47 & 74.83 & 1 & 2.47 & 43 & 91 \\
\hline -EL & 2 & 3.18 & 0 & & 0 & 2 \\
\hline TOTAL & $\mathbf{4 9}$ & $\mathbf{7 8 . 0 1}$ & $\mathbf{2}$ & $\mathbf{4 . 9 4}$ & $\mathbf{1 1 2}$ & $\mathbf{1 6 3}$ \\
\hline
\end{tabular}

Table 8: Concrete noun suffixes: Germanic origin

\begin{tabular}{|l|l|l|l|l|l|l|}
\hline & Surgical & $\mathbf{n f}$ & $\begin{array}{l}\text { Specialised } \\
\text { texts }\end{array}$ & $\mathbf{n f}$ & $\begin{array}{l}\text { Remedies and } \\
\text { materia medica }\end{array}$ & TOTAL \\
\hline -ANT & 15 & 23.88 & 12 & 29.71 & 34 & 61 \\
\hline -ARD & 3 & 4.77 & 1 & 2.47 & 14 & 18 \\
\hline -ARY & 4 & 6.36 & 49 & 121.32 & 53 & 106 \\
\hline -EREL & 0 & 0 & 0 & 0 & 1 & 1 \\
\hline -ESSE & 1 & 1.59 & 2 & 4.95 & 0 & 3 \\
\hline -IST & 0 & 0 & 0 & 0 & 0 & 0 \\
\hline -ISTRE & 28 & 44.58 & 2 & 4.95 & 7 & 37 \\
\hline -OUR & 74 & 117.81 & 10 & 24.76 & 0 & 84 \\
\hline TOTAL & 125 & $\mathbf{1 9 8 . 9 9}$ & 76 & $\mathbf{1 8 8 . 1 6}$ & $\mathbf{1 0 9}$ & $\mathbf{3 1 0}$ \\
\hline
\end{tabular}

Table 9: Concrete noun suffixes: Romance origin

As Kastovsky (2006: 239) has explained, -end and -ere were rival suffixes to form agent nouns, -end being especially productive but lost in ME. In my samples here only -ere is recorded. Neither-ild nor -estre are seen. -Estre indicated female but this reference was lost in ME since ModE gender nouns are not gender-specific (gangster) any longer.

As can be observed from the above tables, the concrete suffixes of Germanic origin that occur in Medieval medical texts are -ling (91 tokens), -ere (70 tokens) and -el (2 tokens). Most 
examples, as was expected, were found in remedybooks (112), followed by surgical treatises (78.01) and specialised texts (4.94). The scarcity of cases in the latter group once more evinces a relationship between audience and text type. Concrete noun suffixes of Romance provenance are not only more frequently used but also a wider range of types can be observed. Frequency of occurrence and variety can account for a writer's preference for these suffixes which, in turn, are more frequent in the sort of terminology used in writings about a specific field, as is the case of medicine. -Ary is the most frequent suffix (106 tokens) followed by -our (84 tokens), -ant (61 tokens) and -istre (37 tokens). Normalised figures indicate that surgical treatises contain the largest number of forms (198.99), followed by specialised texts (188.16) and remedybooks (109). It is not surprising, however, to note that concrete suffixes of Romance origin are more abundant in a text type intended for practitioners in which concrete explanations and instructions are to be conveyed. The scholastic tradition, based on argumentation, elaboration, quotation and explanation, still present in some of these texts could explain the frequent use of Romance forms (not only in morphology but also in syntactic structures (cf. Taavitsainen 2001)).

\subsubsection{Text type/genre}

Remedybooks, in which the terminology used generally names diseases, parts of the body, herbs and the like, but in which definitions and long explanations about processes, states, etc. are typically not provided, contain the highest number of concrete suffixes (221). Surgical treatises come next (138.50). Finally, concrete suffixes in specialised texts are also relatively well represented (89.25). In the remedybook text type, medicine is explained from an empirical point of view.

\begin{tabular}{|l|l|l|l|l|l|}
\hline & Surgical & $\mathbf{n f}$ & Specialised texts & $\mathbf{n f}$ & $\begin{array}{l}\text { Remedies and } \\
\text { materia medica }\end{array}$ \\
\hline Romance & 125 & 68.46 & 76 & 44.02 & 109 \\
\hline Germanic & 49 & 70.34 & 2 & 45.23 & 112 \\
\hline TOTAL & 174 & $\mathbf{1 3 8 . 8 0}$ & 78 & $\mathbf{8 9 . 2 5}$ & $\mathbf{2 2 1}$ \\
\hline
\end{tabular}

Table 10: Concrete noun suffixes in different writing traditions

In terms of productivity, the low occurrence of concrete noun suffixes could be related to the sort of specialised information that is being conveyed: medicine is field-specific and a threestep process is involved when writing about medicine:

1. A translation of classical authoritative texts is needed for the transmission of knowledge. Latin was the language of science and as such dominated the way in which information was transmitted (abstract suffixes).

2. Vernacular capacities are limited. It is necessary to introduce a new word stock (predominance of Romance).

3. Stylistic patterns from prestigious languages are imitated (abstract noun suffixes of classical origin, mainly Latin).

These reasons might justify the predominance of highly specific and abstract nouns of classical provenance, which stands in contrast to the low presence of concrete noun suffixes. 


\section{$5 \quad$ Concluding remarks}

In the analysis here I have not found an overwhelming difference between suffixes of Romance and Germanic origin, in general or by text type. This relative balance seems to point to a regular vernacularisation process that is playing a part in the proto-scientific discourse of late Middle English. In principle this finding helps to confirm the relevance of native resources in particular domains of English, but further scrutiny of concrete noun suffixes and a more detailed study of hybrid formations would be necessary in order to arrive at more conclusive results. There does, however, seem to be a correlation between the abstract meaning of nouns, the level of technicality that a text aims at transmitting and the degree of learnedness of the addressee. This is shown in Figure 1:

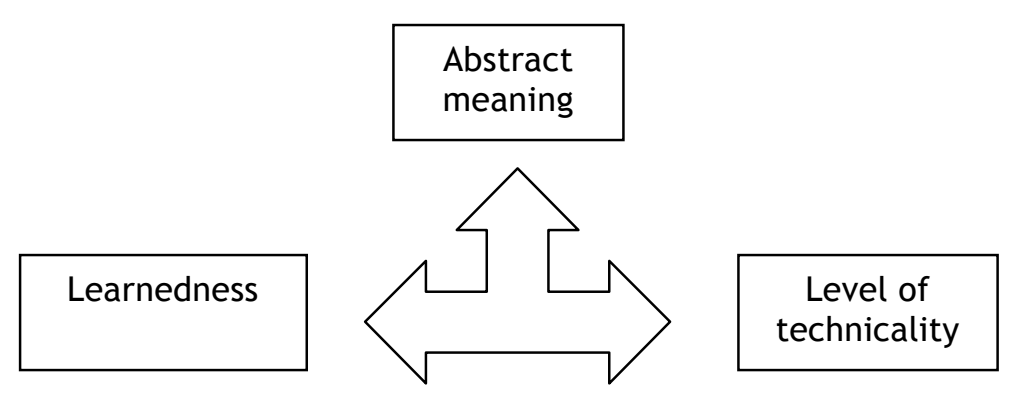

Figure 1: Correlation of factors

The higher the level of technicality, the greater the abstraction and the more learned the addressees. This is especially important if considered from the perspective of the social function that language plays. Concreteness as expressed by noun suffixes is necessary in surgical treatises and remedybooks, which have a practical purpose, the texts intended for medical practitioners or women involved in medical matters; complex nouns more frequently contain abstract suffixes when they are in specialised texts intended for scholars and other learned men. Elementary instruction was without doubt the function of vernacular medical texts, this also confirmed by the presence of doublets serving as "mini-glosses", given that a great many texts were not originally written in English but were translated from Latin. Consequently, the findings here seem to confirm my initial suspicions: that the use of a particular language is associated to different kinds of audience. Latin and its patterns are associated to the learned whereas the vernacular is associated to the non-learned. Notwithstanding, the social value of writing in English or translating into English grew into the very development of the vernacular. And, from a morphological point of view, this was in accordance with the gradually increasing frequency of use of Germanic noun suffixes.

Finally, it may not be the case that Germanic suffixes, as Dalton-Puffer and Jakubowsky have maintained, are more productive than Romance ones. According to the data analysed, I would suggest, rather, that they are more flexible. Similar figures in both Romance and Germanic abstract noun suffixes seem to point towards the path of vernacularisation of Medieval medical texts.

\section{References}

Bauer, Laurie (1983): English Word-Formation. Cambridge: Cambridge University Press. Burnley, David (1992): "Lexis and semantics". In: Blake, Norman (ed.) (1992): The Cambridge history of the English language: 1066-1476. Cambridge, Cambridge University Press: 409-499. 
Castairs-Mccarthy, Alistair (2002): An introduction to English morphology. Edinburgh: Edinburgh University Press.

Ciszek, Ewa (2006): "LME -SHIP(E)". Studia Anglica Posnaniensia 42: 179-187.

Crespo, Begoña (forthcoming): Change in Life, Change in Language. A semantic approach to the history of English. Bern. (= Studies in Medieval English).

Crespo, Begoña/Moskowich, Isabel (2009): "'The Limits of my Language are the Limits of my World': The Scientific Lexicon from 1350 to 1640". Skase Journal of Theoretical Linguistics 6/1: 45-58.

Dahl, Trine (1989): "Compound Adjectives in English General and Special Language". In: Breivik, Leiv Egil et al. (eds.) (1989): Essays on English Language in Honour of Bertil Sundby. Oslo: Novus. (= Studia Anglistica Norvegica 4).

Dalton-Puffer, Christiane (1996): The French Influence on Middle English Morphology. A Corpus-based Study of Derivation. Berlin: De Gruyter.

Getz, Faye (1998): Medicine in the English Middle Ages. Princeton: Princeton University Press.

Gotti, Maurizio (2011): "The development of specialized discourse in the Philosophical Transactions". In: Taavitsainen, Irma/Pahta, Päivi (eds.) (2011): Medical Writing in Early Modern English. Cambridge, Cambridge University Press: 204-220.

Görlach, Manfred (2003): Topics in English Historical Linguistics. Heidelberg: Winter.

Halliday, Michael A. K. (1978): "Sociolinguistic Aspects of Mathematical Education". In: Halliday, Michael A. K. (ed.) (1978): Language as Social Semiotic. London, Arnold: 194204.

Jakubowski, Piotr (2006): "On Derivational Suffixes in Three Late Middle English Romances: Guy of Warwick, Bevis of Hampton and Sultan of Babylon". Studia Anglica Posnaniensia 42: 189-201.

Kaplan, Robert B. (2001): "English - the Accidental Language of Science?". In: Ammon, Ulrich (ed.) (2001): The Dominance of English as a Language of Science. Effects on Other Languages and Language Communities. Berlin, De Gruyter: 3-26.

Kastovsky, Dieter (2006): "Vocabulary". In: Denison, David/Hogg, Richard (eds.) (2006): A History of the English Language. Cambridge, Cambridge University Press: 199-270.

Labov, William (1972): Sociolinguistic Patterns. Philadelphia: University of Pennsylvania Press.

Lareo Martín, Inés (2009): "El Coruña Corpus. Proceso de compilación y utilidades del Corpus of English Texts on Astronomy (CETA). Resultados preliminares sobre el uso de los predicados complejos en CETA". In: Cantos Gómez, Pascual/Sánchez Pérez, Aquilino (eds.) (2009): A Survey on Corpus-based Research. Panorama de investigaciones basadas en corpus. Murcia, AELINCO: 267-280.

Lenski, Daniel (2000): "The Status of Etymology in the Synchronic Morphology of English". http://myxo.css.msu.edu/dlenski/academic/The_Status_of_Etymology_in_the_Synchronic_ Morphology_of_English.pdf, accessed December 12, 2012.

Marchand, Hans (1969): The Categories and Types of Present-day English Word-formation. Munich: Otto Harrassowitz.

Matthews, Peter H. (1974): Morphology. Cambridge: Cambridge University Press.

McIntyre, Dan (2008): History of English. London/New York: Routledge.

Moskowich, Isabel (2009): "'Of medicine3 sedatyue3': Some notes on adjective position and oral register in Middle English medical texts". Studia Anglica Posnaniensia 45/1: 57-68.

Nevalainen, Terttu (1999): "Early Modern English lexis and semantics". In: Lass, Roger (ed.) (1999): The Cambridge history of the English language. Volume III. 1476-1776. Cambridge, Cambridge University Press: 332-458.

Norri, Juhani (1998): Names of Body Parts in English, 1400-1550. Helsinki. (= Annales Academiae Scientiarum Fennicae, Humaniora 291). 
Pahta, Päivi/Taavitsainen, Irma (2004): "Vernacularisation of scientific and medical writing in its sociohistorical context". In: Taavitsainen, Irma/Pahta, Päivi (eds.) (2004): Medical and Scientific Writing in Late Medieval English. Cambridge, Cambridge University Press: $1-22$.

Plag, Ingo (2003): Word-formation in English. Cambridge: Cambridge University Press.

Rundblad, Gabriella (1998): Shallow brooks and rivers wide. Study of lexical and semantic change in English nouns denoting "watercourse". Stockholm: Almqvist \& Wiksell.

Sager, Juan C./Dungworth, David/Mcdonald, Peter F. (1980): English Special Languages. Principles and Practise in Science and Technology. Wiesbaden: Brandstetter.

Taavitsainen, Irma (2001): "Language history and the scientific register". In: Görlach, Manfred/Jürgen-Diller, Hans (eds.) (2001): Towards a History of English as a History of Genres. Heidelberg, Winter: 185-202.

Taavitsainen, Irma (2004): "Transferring classical discourse conventions into the vernacular". In: Taavitsainen, Irma/Pahta, Päivi (eds.) (2004): Medical and Scientific Writing in Late Medieval English. Cambridge, Cambridge University Press: 37-72.

Taavitsainen, Irma/Pahta, Päivi (1997): "Corpus of Early English medical writing 13751750". ICAME Journal 21: 71-88.

Taavitsainen, Irma/Pahta, Päivi/Mäkinen, Martti (2005): Middle English Medical Texts corpus (MEMT) including MEMT Presenter by Raymond Hickey. Amsterdam/New York.

Voigts, Linda Ehrsam (1989): "Scientific and medical books". In: Griffiths, Jeremy/Pearsall, Derek (eds.) (1989): Book Production and Publishing in Britain, 1375-1475. Cambridge, Cambridge University Press: 345-402. 